\title{
Pengembangan Bahan Ajar Berbasis Visual dan Realistik bagi Siswa Tunarungu
}

\author{
Samuel Igo Leton ${ }^{1}$, Meryani Lakapu ${ }^{2}$, Kristoforus Djawa Djong ${ }^{3}$, Yohanes \\ Ovaritus Jagom ${ }^{4}$, Irmina Veronika Uskono ${ }^{5}$, Wilfridus Beda Nuba \\ Dosinaeng 6 \\ 1,2,3,4,5,6Program studi pendidikan matematika, Universitas Katolik Widya Mandira, Kupang; \\ Indonesia; letonsamuel@unwira.ac.id ${ }^{1 *}$; meryanilakapu@gmail.com ${ }^{2}$; djongflores@gmail.com ${ }^{3}$; \\ jagom2020@unwira.ac.id ${ }^{4} ;$ veniuskonu@gmail.com ${ }^{5} ;$ willfridusdosinaeng@unwira.ac.id $^{6}$
}

Info Artikel: Dikirim: 1 Januari 2021; Direvisi: 6 Maret 2021; Diterima: 9 Maret 2021

Cara sitasi: Leton, S. I., Lakapu, M., Djong, K. D., Jagom, Y. O., Uskono, I. V., \& Dosinaeng, W. B. N. (2021). Pengembangan Bahan Ajar Berbasis Visual dan Realistik bagi Siswa Tunarungu. JNPM (Jurnal Nasional Pendidikan Matematika) 5(1), 23-36.

\begin{abstract}
Abstrak. Salah satu faktor penyebab pembelajaran matematika di SMPLB berjalan kurang maksimal adalah pengunaan bahan ajar. Bahan ajar yang digunakan oleh guru dalam pembelajaran pada anak-anak tunarungu di SMPLB di Kota Kupang masih menggunakan bahan ajar yang sama dengan siswa normal. maka perlu adanya bahan ajar yang sesuai dengan kebutuhan dan karakteristik mereka. Penelitian ini bertujuan untuk menghasilkan sebuah buku matematika khusus untuk anak-anak tunarungu, yang berbasis pada visualisasi dan realistik. Metode yang digunakan adalah metode pengembangan dengan model 4D rancangan Thaiagaradjan dimana terdiri dari empat tahap yaitu, pendefinisian (define), perancangan (design), pengembangan (develop), dan penyebaran. Instrumen yang dikembangkan dalam penelitian ini terdiri atas enam macam, yakni (1) lembar validasi bahan ajar, (2) lembar keterbacaan bahan ajar, (3) lembar observasi aktivitas guru, (4) lembar observasi aktivitas anak-anak tunarungu, (5) angket respon anak-anak tunarungu dan (6) lembar tes tulis. Indicator penilaian dari penelitian pengembangan ini meliputi valid, praktis dan efektif. Hasil analisis menunjukkan bahan ajar yang dikembangkan memenuhi kriteria valid, praktis dan efektif, sehingga bahan ajar tersebut berkulaitas baik dan dapat digunakan dalam pembelajaran matematika bagi siswa SMPLB Kelas VII.
\end{abstract}

Kata Kunci: Tunarunggu, Bahan Ajar, Visual, Realistik, Matematika.

\begin{abstract}
One of the factors that causes mathematics learning at SMPLB to run less optimally is the use of teaching materials. The teaching materials used by teachers when teaching deaf children at SMPLB in Kupang City still use general teaching materials, so it is necessary to have teaching materials according to the needs and characteristics of children with hearing impairment. This study aims to produce a special mathematics book for deaf children, with the first step taken is to make teaching materials based on visualization and realistics where visual ability is their advantage. The method used is a development method with the 4D model designed by Thaiagaradjan which consists of four stages, namely, the defining stage, the design stage, the develop stage, the deployment stage. The instruments developed in this study consisted of six types, namely (1) validation of teaching materials, (2) readability of teaching materials, (3) teacher activity observation sheets, (4) student activity observation sheets, (5) response questionnaires. deaf children and (6) written test sheets. The assessment indicators of this development research include valid, practical and effective. The results of the analysis show that
\end{abstract}


the teaching materials developed meet the criteria of validity, practicality and effectiveness, so that the teaching materials are of good quality and can be used in mathematics learning for Class VII SMPLB students.

Keywords: Deaf, Teaching Materials, Visual, Realistic, Mathematics.

\section{Pendahuluan}

Pelajaran matematika di sekolah dipelajari oleh semua siswa baik pada jenjang pendidikan dasar, menengah maupun pendidikan tinggi. Undang-Undang Nomor 20 Tahun 2003 menjamin setiap warga negara mempunyai hak yang sama untuk memperoleh pendidikan yang bermutu, dan setiap warga negara yang memiliki potensi kecerdasan dan bakat istimewa berhak memperoleh pendidikan khusus. Anak-anak yang mengalami gangguan pendengaran (tunarungu) memperoleh mata pelajaran matematika melalui jalur pendidikan khusus yang disebut dengan Sekolah Dasar Luar Biasa (SDLB), Sekolah Menengah Pertama Luar Biasa (SMPLB) dan Sekolah Menengah Atas Luar Biasa (SMALB).

Anak-anak tunarungu merupakan anak yang mengalami gangguan fungsi pendengaran baik sebagian maupun seluruhnya yang berdampak kompleks dalam kehidupannya. Mereka secara fisik terlihat seperti anak normal, tetapi bila diajak berkomunikasi barulah terlihat bahwa mereka mengalami gangguan pendengaran. Anak tunarungu tidak berarti mereka itu tunawicara, akan tetapi pada umumnya mereka mengalami ketunaan sekunder yaitu tunawicara. Penyebabnya adalah mereka sangat sedikit memiliki kosakata dalam sistem otak dan siswa tidak terbiasa berbicara. Mereka memiliki tingkat intelegensi bervariasi dari yang rendah hingga jenius. Hal ini disebabkan oleh perolehan informasi dan pemahaman bahasa lebih sedikit bila dibandingkan dengan siswa normal. Mereka pada umumnya mendapatkan informasi dari indera yang masih berfungsi, seperti indera penglihatan, perabaan, pengecapan, dan penciuman (Dormal, Crollen, Baumans, Lepore, Collignon, $\underline{2016})$.

Mereka juga memiliki inteligensi yang sama dengan anak normal, akan tetapi karena perkembangan bahasa mempengaruhi perkembangan inteligensi, maka mereka memiliki inteligensi yang lebih rendah dari anak normal (Akram, Rabia, Anum, Rukhsana, 2013). Hal ini diakibatkan oleh kesulitan mereka dalam memahami bahasa yang menyebabkan keterbatasan mereka dalam memperoleh informasi, bahasa, kurang dalam kosa kata, sulit dalam mengerti ungkapan bahasa yang mengandung arti kiasan dan kata-kata abstrak (Leton, Wahyudin, Dosinaeng, 2019). Mereka lebih membutuhkan waktu yang banyak untuk belajar menghubungkan keterkaitan antar konsepkonsep matematis dan mengkomunikasikannya (Vosganoff, Paatsch, Toe, 
2011). Hasil kajian yang dilakukan oleh Martin (Leton, 2018) menemukan bahwa pada umumnya, anak tunarungu kurang menggunakan potensi kognitif yang dimiliki sampai batas maksimal dalam memproses informasi. Hal ini menyebabkan keterampilan kognitif yang dimiliki oleh mereka lebih rendah jika dibandingkan dengan anak-anak normal normal (Barbosa, 2014). Mereka kurang menggunakan potensi kognitif yang dimiliki sampai batas maksimal dalam memproses infomasi karena keterbatasan dalam komunikasi dan pemecahan masalah (Foisack, 2005).

Karena anak-anak tunarungu memiliki keterbatasan seperti yang telah disampaikan sebelumnya, hal ini menyebabkan prestasi belajar mereka lebih rendah jika dibandingkan dengan siswa normal untuk materi pelajaran yang bersifat abstrak (Pagliaro, 2012). Walaupun anak-anak tunarungu memiliki keterbatasan dalam mendengar, bukan berarti mereka tidak bisa mengikuti kegiatan proses pembelajaran. Keterbatasan dalam kemampuan auditory dapat diatasi dengan kemampuan visual yang dimilikinya. Mereka memiliki kemampuan matematis terbaik yang berkaitan dengan visual (Blatto-Vallee, 2005b). Selain itu, mereka juga memiliki kelebihan lainnya yakni kemampuan matematis pada bidang, ruang, dan pengukuran yang menggunakan keterampilan visuo-spasial (Leton, Lakapu, \& Dosinaeng, 2019). Keterampilan aritmetika sederhana dalam melakukan perhitungan lisan dengan menggunakan bahasa isyarat juga merupakan kelebihan lain yang mereka miliki (Nunes, 2002). Visual yang terdiri atas gambar atau benda-benda konkret sangat bermanfaat bagi anak-anak tunarungu (Swanwick, 2016). Dalam membangun pemahaman terhadap suatu kosep, ada kecenderungan anak-anak tunarungu merepresentasikan masalah dalam bentuk visual (Leton, 2018). Visual bermanfaat bagi anak-anak tunarungu sebagai media yang menjembatani antara hal-hal yang konkret dengan hal-hal yang bersifat absrak (Nikolaraizi, Vekiri, Easterbrooks, Susan, 2013). Dengan demikian, diharapkan bahwa gangguan pendengaran yang dimiliki oleh anak-anak tunarungu ini, bukanlah penyebab langsung kesulitan bagi anak-anak tunarungu dalam belajar matematika.

Berdasarkan hasil studi pendahuluan di beberapa SLB di Kota Kupang, ditemukan informasi bahwa bahan ajar matematika yang digunakan selama ini di sekolah-sekolah bukan merupakan bahan ajar matematika khusus untuk anak-anak tunarungu. Buku ajar yang digunakan sama seperti siswa normal lainya sehingga isi yang terkandung di dalam buku ajar tersebut tidak sesuai dengan karakeristik siswa tunarungu. Selain itu, kami juga memperoleh infomasi bahwa guru matematika yang ada pada sekolah-sekolah tersebut kurang memiliki keterampilan bahasa layaknya guru SMPLB pada umumnya. 
Ini disebabkan karena latarbelakangnya adalah pendidikan matematika umum bukan dari pendidikan luar biasa. di kelas tidak berjalan maksimal. Selain itu, persepsi tentang matematika merupakan pelajaran yang sulit, ternyata juga terjadi di Sekolah Luar Biasa. Kami menduga bahwa, bahan ajar yang tidak sesuai dengan kebutuhan dan karakteristik, menyebabkan guru kesulitan dalam mentransfer materi tersebut kepada anak-anak tunarungu. Ini yang menjadi salah satu faktor yang menyebabkan pembelajaran matematika tidak berjalan secara maksimal. Terhadap permasalahan di atas, penelitian ini bertujuan untuk menghasilkan sebuah buku paket matematika khusus untuk anak-anak tunarungu kelas VII.

\section{Metode}

Metode yang digunakan dalam penelitian ini adalah Penelitian dan Pengembangan (research and development / RED) dengan model 4D rancangan Thaiagaradjan yang terdiri atas empat tahap yaitu, pendefinisian (define), perancangan (design), pengembangan (develop), dan penyebaran (disseminate) (Thiagarajan, Semmel, \& Semmel, 1974). Namun, pelaksanaan penelitian ini terbatas sampai pada tahap pengembangan (develop), karena keterbatasan situasi dan waktu.

Sekolah-sekolah yang akan dijadikan tempat uji coba baik uji coba kelompok kecil maupun uji coba kelompok besar akan dipilih dari seluruh SMPLB yang tersebar Kota Kupang - NTT. Instrumen yang dikembangkan dalam penelitian ini seperti terlihat pada Tabel 1.

Tabel 1. Macam Instument yang Dikembangkan

\begin{tabular}{|c|c|c|c|}
\hline $\begin{array}{l}\text { Aspek yang } \\
\text { dinilai }\end{array}$ & Instrument & Data yang direkam & Responden \\
\hline Kevalidan & Lembar validasi & Kevalidan Bahan Ajar & \multirow{2}{*}{$\begin{array}{l}\text { Validator } \\
\text { Subjek } \\
\text { penelitian }\end{array}$} \\
\hline Bahan Ajar & Lembar keterbacaan & Kevalidan Bahan Ajar & \\
\hline Kepraktisan & Lembar aktivitas guru & $\begin{array}{l}\text { Keterlaksanaan Bahan } \\
\text { Ajar }\end{array}$ & \multirow{2}{*}{ Pengamat } \\
\hline Bahan Ajar & $\begin{array}{l}\text { Lembar aktivitas anak- } \\
\text { anak tunarungu }\end{array}$ & $\begin{array}{l}\text { Aktivitas anak-anak } \\
\text { tunarungu }\end{array}$ & \\
\hline $\begin{array}{l}\text { Keefektifan } \\
\text { Bahan Ajar }\end{array}$ & $\begin{array}{l}\text { Angket respon } \\
\text { anak-anak tunarungu } \\
\text { Tes tulis }\end{array}$ & $\begin{array}{l}\text { Respon anak-anak } \\
\text { tunarungu } \\
\text { Penguasaan Bahan Ajar }\end{array}$ & $\begin{array}{l}\text { Subjek } \\
\text { penelitian }\end{array}$ \\
\hline
\end{tabular}

Lembar validasi dan lembar keterbacaan terdiri atas 2 bagian yaitu skor saran dan penilaian. Skor yang diberikan untuk setiap butir pernyataan menggunakan skala likert dengan lima tingkatan untuk lembar validasi dan empat tingkatan untuk lembar keterbacaan. Untuk mengetahui kepraktisan 
bahan ajar yang dikembangkan digunakan lembar observasi. Lembar observasi ini dibuat untuk merekam keterlaksanaan pembelajaran sesuai dengan RPP dan untuk merekam aktivitas anak-anak tunarungu selama proses pembelajaran. Skor yang diberikan untuk setiap butir pernyataan menggunakan skala likert dengan pilihan jawaban sangat aktif diberi skor 5, aktif diberi skor 4, cukup aktif diberi skor 3, kurang aktif diberi skor 2 dan tidak aktif diberi skor 1 . Dengan demikian skor maskimal yang diperoleh pengamat pada lembar observasi aktivitas guru yaitu 70 dan pada lembar observasi aktivitas anak-anak tunarungu yaitu 35. Untuk mengetahui keefektifan bahan ajar digunakan angket respons dan tes hasil belajar. Angket respons disusun berdasarkan beberapa indicator, antara lain: kemenarikkan bahan ajar; kemudahan dalam penggunaan bahan ajar; dan suasana saat pembelajaran. sedangkan untuk tes hasil belajar diberikan setelah pelaksanaan penelitian. Tes ini dilakukan untuk mengetahui tingkat ketuntasan belajar secara individu. Teknik analisis data berupa kevalidan bahan ajar dengan kriteria kelayakkan, kepraktisan dan keefektifan bahan ajar dengan kriteria pada Tabel 2.

Tabel 2. Kriteria Kevalidan, Kepraktisan dan Keefektifan Bahan Ajar

\begin{tabular}{|c|c|c|c|c|c|}
\hline \multicolumn{2}{|c|}{ Kevalidan } & \multicolumn{2}{|c|}{ Kepraktisan } & \multicolumn{2}{|c|}{ Keefektifan } \\
\hline $\begin{array}{c}\text { Interval } \\
\text { skor }\end{array}$ & Kriteria & $\begin{array}{c}\text { Tingkat } \\
\text { pencapaian }\end{array}$ & Kategori & Rentang skor & Kategori \\
\hline $0-1,8$ & Tidak Valid & $90 \%-100 \%$ & $\begin{array}{l}\text { Sangat } \\
\text { Praktis }\end{array}$ & Rs $<50 \%$ & Tidak Positif \\
\hline $1,9-2,6$ & Kurang Valid & $80 \%-89 \%$ & Praktis & $50 \% \leq \mathrm{Rs}<60 \%$ & $\begin{array}{l}\text { Kurang } \\
\text { Positif }\end{array}$ \\
\hline $2,7-3,4$ & Cukup Valid & $65 \%-79 \%$ & $\begin{array}{l}\text { Cukup } \\
\text { Praktis }\end{array}$ & $60 \% \leq \mathrm{Rs}<70 \%$ & $\begin{array}{l}\text { Cukup } \\
\text { Positif }\end{array}$ \\
\hline $3,5-4,2$ & Valid & $55 \%-64 \%$ & $\begin{array}{l}\text { Kurang } \\
\text { Praktis }\end{array}$ & $70 \% \leq \mathrm{Rs}<85 \%$ & Positif \\
\hline $4,3-5$ & Sangat Valid & $0 \%-54 \%$ & $\begin{array}{l}\text { Tidak } \\
\text { Praktis }\end{array}$ & $85 \% \leq \mathrm{Rs} \leq 100 \%$ & $\begin{array}{l}\text { Sangat } \\
\text { Positif }\end{array}$ \\
\hline
\end{tabular}

\section{Hasil dan Pembahasan}

Suatu produk dikatakan berkualitas baik, jika memenuhi aspek validitas, kepraktisan, keefektifan (Nieveen, 1999). Analisis hasil pengembangan bahan ajar ini mengacu pada model pengembangan 4D (Define, Design, Development, Disseminate) yang dimodifikasi menjadi 3 tahapan yaitu.

\section{Tahap Pendefinisian}

Tahap ini terdiri dari analisis awal-akhir, analisis anak-anak tunarungu, analisis konsep, analisis tugas, dan perumusan tujuan pembelajaran. Tujuan dari tahap ini yaitu untuk menetapkan dan mendefinisikan syarat-syarat kebutuhan dalam proses pembelajaran yang terdapat pada SMPLB. Pada 
analisis awal akhir, kami melakukan observasi terhadap proses pembelajaran di kelas, kurikulum yang digunakan, ketersediaan sumber belajar, dan menelaah tujuan kurikulum 2013. Hasil analisis ini diperoleh gambaran bahwa 1) kegiatan pembelajaran yang berlangsung menjadikan mereka cenderung pasif, karena proses belajar mengajar berpusat pada guru sedangkan mereka hanya mendengar penjelasan dari guru; 2) sumber belajar utama di kelas menggunakan buku matematika umum kurikulum 2013.

Hasil analisis ini diperoleh gambaran bahwa mereka kurang aktif dalam proses pembelajaran dan mereka masih kesulitan dalam memahami konsep dari suatu materi yang diajarkan. Meraka pada umumnya kurang percaya diri, rasa malu, mider ketika ingin mengemukakan ide/pertanyaan. Berdasarkan analisis, kami merekomendasikan perlu adanya bahan ajar yang memfasilitasi anak-anak tunarungu dengan memanfaatkan kelebihan yang dimiliki. Materi yang dikembangkan dalam bahan ajar ini disesuaikan dengan kurikulum dan mengacu pada silabus yang digunakan di sekolah yakni Operasi Bilangan Bulat.

\section{Tahap Perancangan}

Dalam penelitian ini, kami mendesain yang menarik berbasis visual, realistik dan menarik sehingga dapat membangkitkan memotivasi anak-anak tunarungu dalam mempelajari materi pembelajaran. Hasil desain awal gambar-gambar pada bahan ajar ditunjukan pada gambar 1.

Mempertimbangkan kelebihan kemampuan yang dimiliki oleh anak-anak tunarungu dalam bidang visual (Blatto-Vallee, 2005a) maka kami mendesain bahan ajar menggunakan gambar yang menarik, yang sudah dikenal oleh mereka yakni semut. Hasil uji coba, menunjukkan bahwa mereka terlihat antusias mengikuti langkah-langkah atau tahapan yang dilakukan dalam memahami contoh yang diberikan. Mereka memahami kalimat-kalimat yang terkandung dalam bahan ajar tersebut. Hal ini disebabkan karena kalimat yang digunakan tidak terlalu panjang dan kata-katanya sudah familiar bagi mereka. Ketika menggunakan bahasa/kata-kata yang baru (yang belum diketahui) mereka akan kesulitan memahaminya. Bahasa berpengaruh terhadap performan kemampuan matematis anak tunarungu (Zevenbergen, Hyde, Power, 2001). 


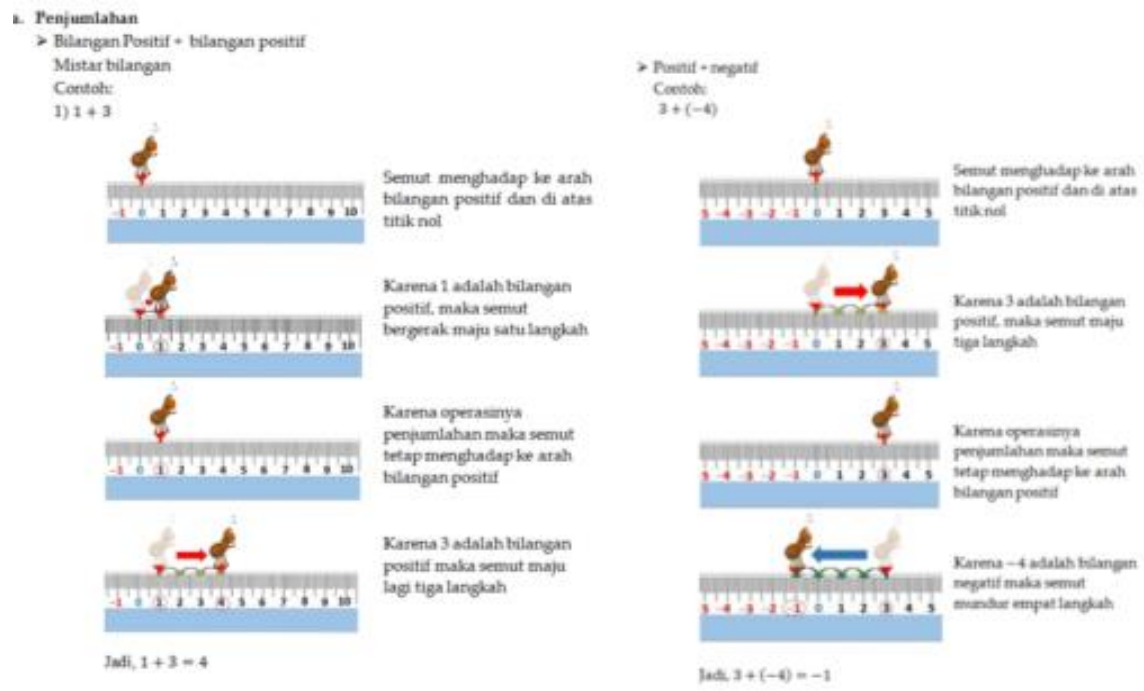

Gambar 1. Desaian Awal Bahan Ajar pada Operasi Penjumlahan

Gambar 2 menunjukan operasi pengurangan, kami juga mengunakan gambar semut sebagai model dalam peragaan. Pada awal peragaan, mereka sedikit mengalami kesulitan dalam memahami kata berbalik arah. Hal ini disebabkan kata berbalik arah belum pernah didengar. Mereka paham dengan kata 'putar muka' sehingga kami menggantikan kata berbalik arah dengan kata putar muka.

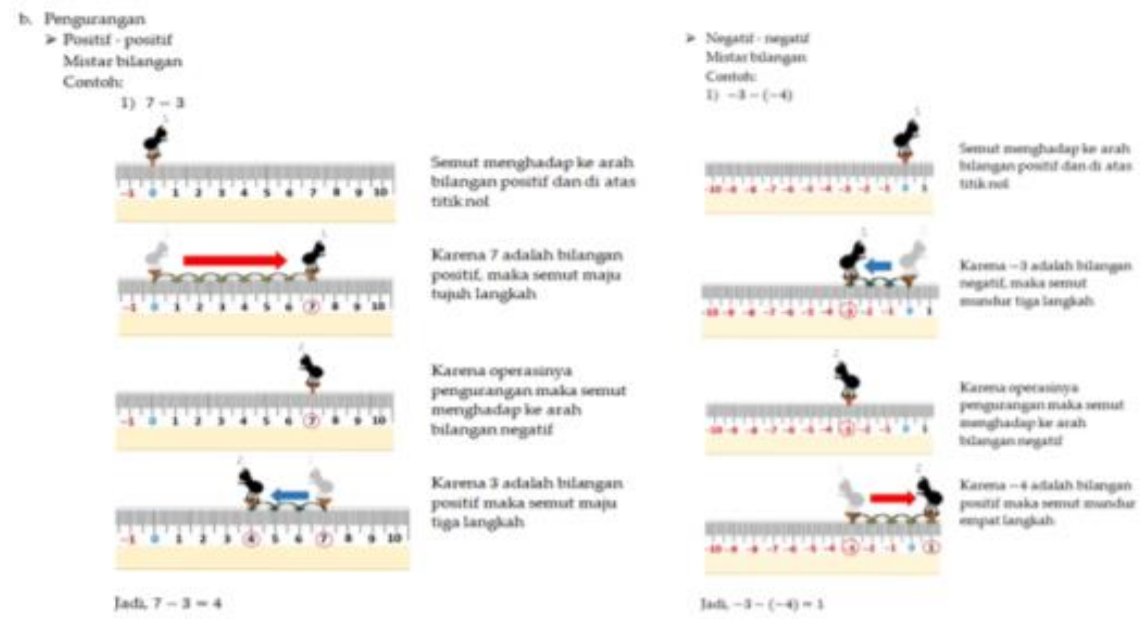

Gambar 2. Desain Awal Bahan Ajar pada Operasi Pengurangan

Pada umumnya anak-anak tunarungu mengalami ketunaan sekunder yaitu tunawicara. Penyebabnya adalah mereka sangat sedikit memiliki kosakata dalam sistem otak (Leton, 2018). Pada operasi pengurangan, mereka membutukan waktu yang lebih banyak untuk memahami peragaan. Kami melihat bahwa hal ini wajar bagi mereka. Mereka membutuhkan waktu yang lebih banyak dari anak normal dalam memahami (Akram, 2013). Ketika 
mereka tidak memahami dengan baik, mereka tidak dapat melakukannya dengan benar (Carrasumada, 1995).

Gambar 3 menunjukkan operasi perkalian, kami menggunakan Kumbang sebagai model. Sebelum melakukan peragaan, anak-anak tunarungu diberi penjelasan terkait cara melakukan peragaan. Pada awalnya mereka sedikit merasa kebinggunan dengan aturan permainan. Untuk membuat mereka lebih mudah memahami aturan peragaan, kami berperan sebagai model melakukan peragaan terkait operasi perkalian pada dua bilangan bulat. Hasil pengamatan menunjukkan mereka terlihat lebih mudah memahami aturan peragaan dan antusias untuk mencoba melakukannya. Bagi anak-anak tunarungu, informasi yang bersumber pada pengelihatan dan motorik akan berkembang dengan cepat (Marschark, Paivio, Spencer, Durkin, Borgna, Convertino, Machmer, 2017).

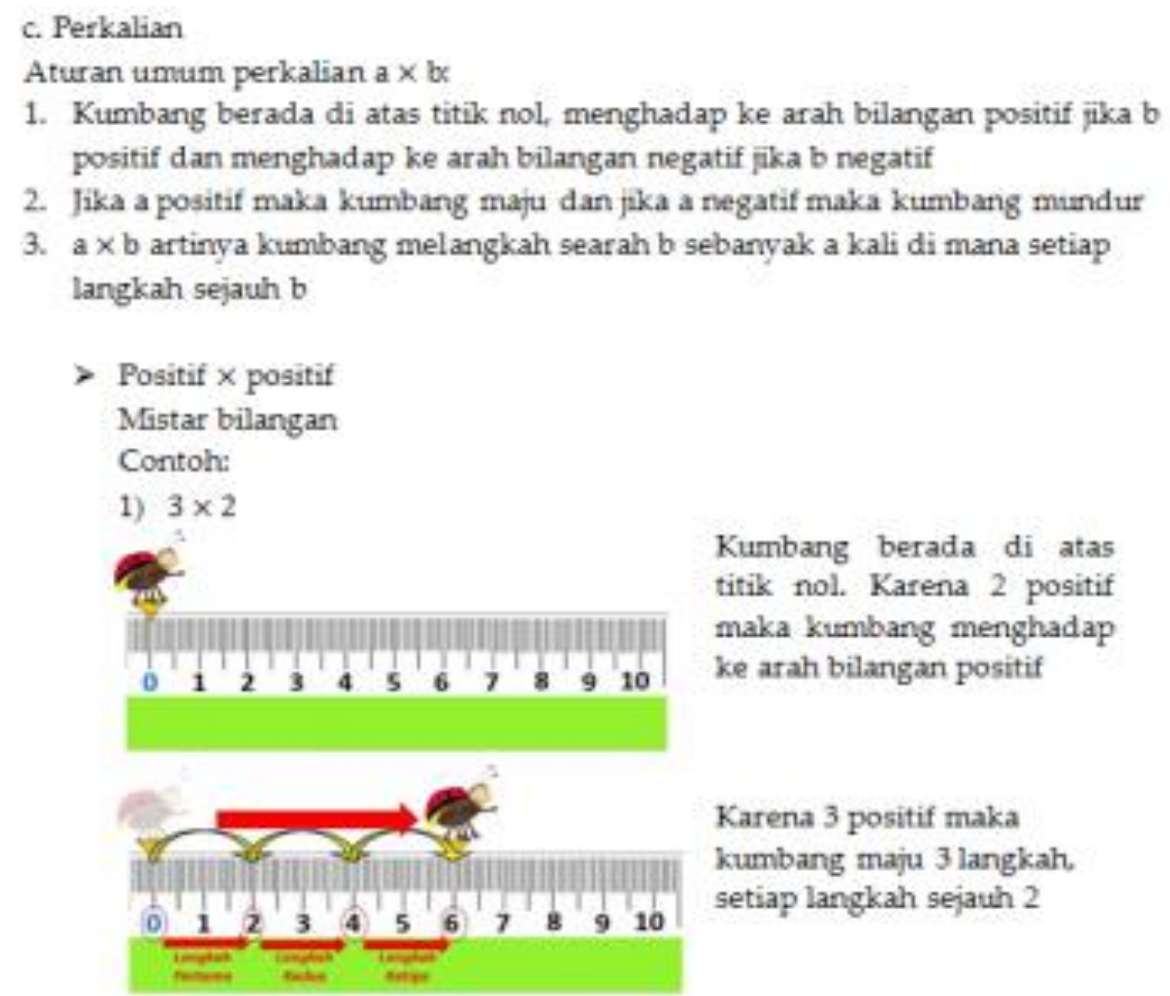

Gambar 3. Desain Awal Bahan Ajar pada Operasi Perkalian

Walaupun pada akhir mereka semua dapat memahami dan dapat melakukan sendiri peragaan dengan benar, namun mereka membutuhkan waktu yang lebih banyak. Anak-anak tunarungu membutuhkan waktu yang lebih banyak dari anak normal dalam memahami suatu konsep (Akram, 2013). 


\section{Pembagian}

turan umum pembagian $\mathrm{a}+\mathrm{b}$ :

Kumbang berada di atas titik a, menghadap ke arah negatif jika a positif, dan menghadap ke arah positif jika a negatif

Perhatikan nilai b. Jika a dan b bertanda sama maka arah kumbang tetap, sedangkan jika a dan b berbeda tanda maka kumbang berbalik arah.

Kumbang selalu melangkah menuju nol, setiap melangkahnya sebanyak b Jika kumbang melangkah maju maka hasil baginya bertanda positif dan angkanya adalah jumlah langkahnya.

Jika kumbang melangkah mundur maka hasil baginya bertanda negatif dan angkanya adalah jumlah langkahnya.

\section{Positif $\div$ positif \\ Mistar bilangan \\ Garis bilangan \\ Contoh:}

1) $8 \div 4$

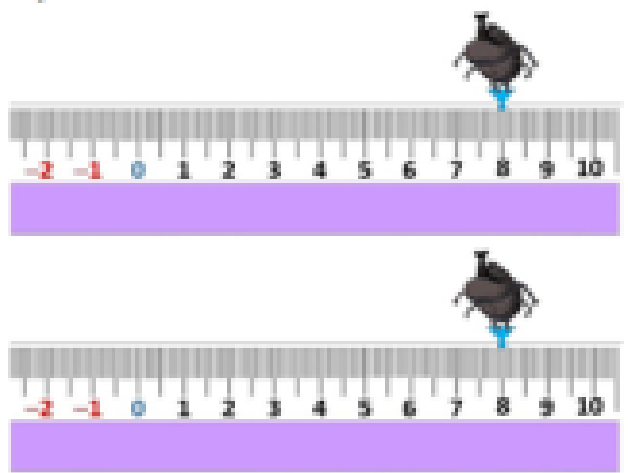

Kumbang berada di atas titik

8. Karena 8 positif maka kumbang menghadap ke arah bilangan negatif.

Karena 4 positif maka kumbang tetap menghadap ke arah bilangan negatif.

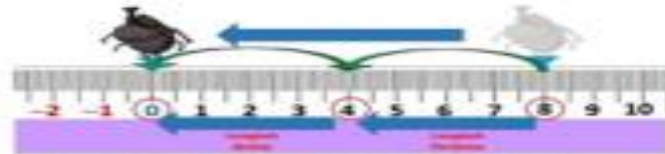

Kumbang melangkah ke titik mol, sekali melangkah 4.

Karena kumbang melangkah maju maka hasilnya bertanda positif. Jadi, $B+4=2$

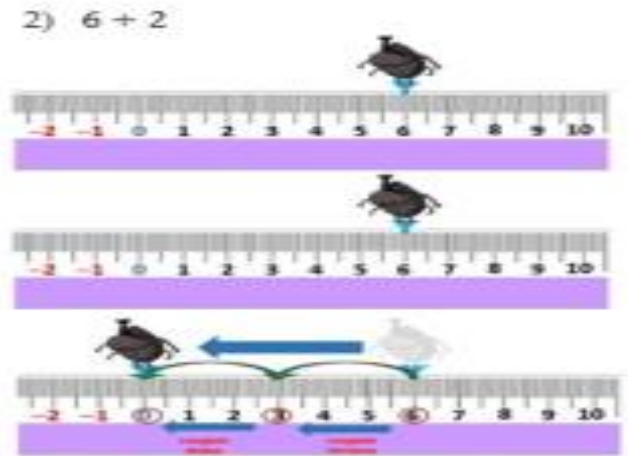

Kumbang berada di atas titik 6. Karena 6 positif maka kumbang menghadap ke arah bilangan negatif.

Karena $z$ positif maka kumbang tetap menghadap ke arah billangan negatif.

Kumbang melangkah ke titik nol, sekali melangkah 2 .

Karena kumbang melangkah maju maka hasilnya bertanda positif. Jadi, $6 \div 2=3$

Gambar 4. Desain Awal Bahan Ajar pada Operasi Pembagian 
Gambar 4 menunjukkan Pada operasi pembagian, kami membutuhkan waktu yang lebih banyak dari operasi pengurangan dan perkalian untuk membuat mereka memahami materi. Mereka sedikit mengalami kesulitan dalam memahami aturan peragaan terlebih pada langkah arah kumbang. Untuk membantu mereka agar lebih mudah memahami peragaan, kami mencoba sebagai model dalam melakukan paragaan. Semua mereka terlihat antusias memperhatikan peragaan yang kami lakukan. Ketika mereka mulai memahami langkah-langkah peragaan, mereka mulai mencoba sebagai model untuk melakukan peragaan dengan benar. Ketika mereka sudah memahami dengan baik mereka akan menunjukkan keterampilan visuo - spasial terhadap suatu masalah yang diberikan kepada mereka spasial (Vosganoff, Paatsch, Toe, 2011). Dan mereka menunjukkan penggunaan strategi yang luar biasa untuk semua jenis masalah (Pagliaro \& Ansell, 2012).

\section{Tahap Pengembangan}

Pada tahap ini, draf bahan ajar yang dihasilkan pada tahap sebelumnya akan diberikan kepada Tim pakar untuk divalidasi. Tim pakar dalam penelitian ini adalah 1 angota tim peneliti dan 2 orang guru matematika pada SMPLB. Hasil validasi oleh masing-masing tim pakar terlihat pada tabel 3.

Tabel 3. Hasil Validasi Bahan Ajar

\begin{tabular}{cccccc}
\hline Validator & Skor & Rata-rata & Nilai & Kategori & Kriteria \\
\hline 1 & 39 & 3.9 & B & Baik & Valid \\
2 & 41 & 4.1 & B & Baik & Valid \\
3 & 47 & 4.7 & B & Baik & valid \\
\hline
\end{tabular}

Tabel 3 menunjukkan bahwa hasil validasi bahan ajar oleh ke tiga validator diperoleh total rata-rata sebesar 4.2 (valid), namun ada beberapa masukan yang perlu dilakukan perbaikan seperti yang terlihat pada tabel 4 .

Tabel 4.Revisi Bahan Ajar Berdasarkan Hasil Validasi

\begin{tabular}{ll}
\hline \multicolumn{1}{c}{ Sebelum Revisi } & \multicolumn{1}{c}{ Sesudah Revisi } \\
\hline $\begin{array}{l}\text { Menggunakan gambar-gambar yang } \\
\text { sudah familiar dan dekat lingkungan } \\
\text { mereka }\end{array}$ & $\begin{array}{l}\text { Menggunakan gambar-gambar yang } \\
\text { sering dijumpai. }\end{array}$ \\
$\begin{array}{l}\text { Gunakan warna yang kontras pada } \\
\text { gambar }\end{array}$ & $\begin{array}{l}\text { membuat warna yang lebih kontras } \\
\text { dan menarik }\end{array}$ \\
$\begin{array}{l}\text { Menggunakan kata-kata yang lebih } \\
\text { simple, singkat dan jelas }\end{array}$ & $\begin{array}{l}\text { Menggunakan kata-kata yang sering } \\
\text { digunakan sehari-hari }\end{array}$ \\
$\begin{array}{l}\text { Petunjuk lebih diperjelas, kalau bisa lebih } \\
\text { singkat" }\end{array}$ & Telah diperbaiki \\
\hline
\end{tabular}


Tahap selanjutnya, bahan ajar yang sudah diperbaiki berdasarkan saran validator diujicobakan secara terbatas untuk mengetahui kevalidan bahan ajar berdasarkan persepsi anak-anak tunarungu. Uji coba dilakukan di dua SMPLB yang berada di kota Kupang. Mereka diminta untuk mengamati, mengomentari serta mengerjakan soal-soal pada bahan ajar tersebut.

Tabel 5. Hasil Uji Keterbacaan Bahan Ajar

\begin{tabular}{ccc}
\hline Responden & Total Skor & Rata-rata \\
\hline Pada sekolah 1 & 34 & 4.8 \\
Pada sekolah 2 & 32 & 4.5 \\
\hline
\end{tabular}

Tabel 5 menunjukkan hasil penilaian bahan ajar menurut persepsi anak-anak tunarungu, diperoleh total rata-rata dari keseluruhan anak-anak tunarungu terhadap penggunaan LKPD sebesar 4.65 (sangat valid). Berdasarkan rekapitulasi hasil validasi oleh para validator dan respon anak-anak tunarungu maka pengembangan bahan ajar berbasis visual dan realistik ini dinyatakan valid. Artinya bahan ajar yang kami kembangkan, memenuhi kriteria "menarik" untuk digunakan sebagai salah satu instrument dalam kegiatan belajar mengajar pada materi operasi bilangan bulat pada siswa kelas VIII SMPLB.

Penilaian kepraktisan bahan ajar diukur melalui hasil analisis lembar pengamatan pengelolaan pembelajaran (aktivitas guru) dan hasil analisis aktivitas anak-anak tunarungu terhadap proses pembelajaran pada 2 sekolah. Hasil analisis terhadap kepraktisan bahan ajar dapat dilihat pada tabel 6 di bawah ini.

Tabel 6. Hasil Analisis Lembar Pengamatan

\begin{tabular}{ccccc}
\hline Sekolah ke - & $\begin{array}{c}\text { Persentase } \\
\text { Aktivitas Guru }\end{array}$ & $\begin{array}{c}\text { Persentase } \\
\text { Aktivitas Anak-anak } \\
\text { tunarungu }\end{array}$ & Rata-rata & Kategori \\
\hline 1 & $86 \%$ & $76 \%$ & $81 \%$ & Praktis \\
2 & $90 \%$ & $82 \%$ & $86 \%$ & Praktis \\
Nilai & $87.5 \%$ & $79 \%$ & $83.5 \%$ & Praktis \\
Kepraktisan & & & & \\
\hline
\end{tabular}

Tabel 6 menunjukan nilai kepraktisan yang diperoleh pada ke 2 sekolah yaitu sebesar $83.5 \%$. Secara umum, bahan ajar yang dikembangkan dalam kategori praktis artinya mudah dipahami, tidak menimbulkan makna yang berbeda oleh anak-anak tunarungu pada kedua sekolah tersebut. Penilaian keefektifan bahan ajar ini diukur berdasarkan hasil analisis angket respons anak-anak tunarungu dan hasil tes belajar. Nilai rata-rata hasil analisis angket respons anak-anak tunarungu pada sekolah ke 1 yaitu diperoleh nilai sebesar 4.5 dan 
tergolong dalam kategori positif dan pada sekolah ke 2 yaitu 4,3 juga dalam kategori baik. Hasil belajar dapat dilihat pada tabel 7.

Tabel 7. Analisis Tes Hasil Belajar

\begin{tabular}{cccc}
\hline Rentang Nilai & Kategori & Jumlah & Persentase \\
\hline $85-100$ & Sangat baik & 3 & $20 \%$ \\
$75-84.99$ & Baik & 7 & $33,3 \%$ \\
$65-74.99$ & Cukup & 5 & $46,7 \%$ \\
$45-64.99$ & Kurang & 0 & 0 \\
$0-44.99$ & Gagal & 0 & 0 \\
Jumlah & & 15 & $100 \%$ \\
\hline
\end{tabular}

Tabel 7 menunjukkan nilai rata-rata yang dihasilkan adalah 77,67\%. Dengan demikian nilai rata-rata hasil belajar anak-anak tunarungu dalam proses pembelajaran setelah menerapkan bahan ajar termasuk dalam kategori baik. Bahan ajar yang dikembangkan tersebut, efektif dalam menunjang kegiatan proses pembelajaran matematika pada pokok bahasan operasi bilangan bulat di kelas VII SMPLB.

Bahan ajar yang kami kembangkan di atas, didasari pada kebutuhan dan karakteristik anak-anak tunarungu yang tujuan utamanya adalah membantu mempermudah mereka dalam memahami konsep operasi pada bilangan bulat. Pesan-pesan yang disampaikan, dibuat dalam bentuk gambar yang menarik dan dekat dengan lingkungan mereka. Ketika media itu dapat membuat mereka senang, mereka akan tertarik untuk mempelajarinya (Van der Sandt, 2018). Kami melihat bahwa, mereka pada umumnya memiliki kecenderungan untuk menggunakan bahasa isyarat sebagai bahasa komunikasi keseharian mereka. Ini yang menyebabkan tingkat kesulitan tersendiri bagi anak-anak tunarungu dalam proses pembelajaran matematika (Barros, Nunes, Evans, Burman, 2014). Komunikasi isyarat yang merupakan bahasa keseharian mereka, menyebabkan keterbatasan kosa-kata yang dimiliki sehingga proses membangun pemahaman terhadap suatu konsep akan terhambat (Syafrudin \& Sujarwo, 2019). Karena memiliki keterbatasan dalam kosa-kata, maka sebaiknya proses pembelajaran yang diberikan, dilakukan secara alamiah, dan bersifat visual (Foisack, 2011) karena mereka pada umumnya memilliki kekurangan dalam hal pendengaran (Kuntze, Golos, Enns, 2014). Bahan ajar yang kami kembangkan ini didesain untuk membantu para guru dalam proses pembelajaran dimana kami menyediakan proses uraian materi dan penjelasan secara secara visual, kalimat yang sederhana dan menggunakan kata-kata yang telah familiar. Materi yang disajikan dalam proses pembelajaran sebaiknya mengutamakan unsur visual dan konkret bahkan yang sering dijumpai (Mekonnen, Hannu, Elina, Matti, 
2016), sehingga mempermudah komunikasi saat pembelajaran (Blatto-Vallee, 2005a). Mereka pada umumnya memiliki keterbatasan dalam hal mendengar sehingga pesan/materi yang disampaikan kepada mereka, perlu dibuat berbasis visual dan memberikan dengan contoh-contoh yang kongkrit yang dekat dengan kehidupan keseharian mereka (realistik) (Hyde, Zevenbergen, Power, 2007). Pembelajaran untuk anak-anak tunarungu sebaiknya bersifat konkret agar mudah dipahami oleh mereka (Zakia, Sunardi, Yatinah, 2016).

\section{Simpulan}

Bahan ajar yang dikembangkan memenuhi kriteria valid, praktis dan efektif. Bahan ajar ini dapat dikatakan berkualitas baik dan layak untuk digunakan oleh guru dan anak-anak tunarungu dalam proses pembelajaran matematika pada materi Operasi Bilangan Bulat kelas VII SMPLB. Dengan demikian, diharapkan bahan ajar ini dapat meningkatkan pemahaman konsep mereka serta menjadi daya tarik bagi anak-anak tunarungu untuk belajar matematika.

\section{Daftar Pustaka}

Akram, B., Mehboob, R., Ajaz, A., \& Bashir, R. (2013). Scientific Concepts of Hearing and Deaf Students of Grade VIII. Journal of Elementary Education, 23(1), 1-12.

Barbosa, H. H. (2014). Conceitos matemáticos iniciais e linguagem: um estudo comparativo entre crianças surdas e ouvintes. Educação e Pesquisa, 40(1), 163-179. https://doi.org/10.1590/S1517-97022014000100011

Barros, R., Nunes, T., Evans, D., \& Burman, D. (2014). Improving deaf children's working memory through training. International Journal of Speech \& Language Pathology and Audiology, 2(2), 51-66. https://doi.org/10.12970/2311-1917.2014.02.02.1

Blatto-Vallee, G. (2005a). One of a Kind: Nunes, T. (2004). Teaching mathematics to deaf children. London: Whurr. 177 pages. Paperback. 19.50 (\$36.59). Journal of Deaf Studies and Deaf Education, 10(3), 317-317. https://doi.org/10.1093/deafed/eni033

Blatto-Vallee, G. (2005b). One of a Kind: Nunes, T. (2004). Teaching mathematics to deaf children. London: Whurr. 177 pages. Paperback. 19.50 (\$36.59). Journal of Deaf Studies and Deaf Education. https://doi.org/10.1093/deafed/eni033

Carrasumada, P. S. (1995). The Deaf Child and Solving Problem of Arithmetic: The Importance of Comprehensive Reading. American Annals of the Deaf 140(3), 287-290.

Dormal, V., Crollen, V., Baumans, C., Lepore, F., \& Collignon, O. (2016). Early but not late blindness leads to enhanced arithmetic and working memory abilities. Cortex, 83, 212221. https://doi.org/10.1016/j.cortex.2016.07.016

Foisack, E. (2005). Deaf Children's Concept Formation in Mathematics. Journal of Cognitive Education and Psychology. https://doi.org/10.1891/194589505787382685

Foisack, E. (2011). Deaf Children's Concept Formation in Mathematics. Journal of Cognitive Education and Psychology, 4(3), 375-376. https://doi.org/10.1891/194589505787382685

Hyde, M., Zevenbergen, R., \& Power, D. (2007). Deaf and Hard of Hearing Students' Performance on Arithmetic Word Problems. American Annals of the Deaf, 148(1), 56-64. https://doi.org/10.1353/aad.2003.0003

Kuntze, M., Golos, D., \& Enns, C. (2014). Rethinking literacy: Broadening opportunities for visual learners. Sign Language Studies. 14(2), 203-224. https://doi.org/10.1353/sls.2014.0002 
Leton, S. I. (2018). Kemampuan Koneksi dan Pemecahan Masalah Matematis Serta Kegemaran Belajar Matematika Siswa Tunarungu Kelas VIII. Disertasi. Universitas Pendidikan Indonesi. 1502243.

Leton, S. I., Lakapu, M., Beda, W., \& Dosinaeng, N. (2019). Kemampuan pemecahan masalah pada siswa tunarungu dalam menyelesaikan masalah non nutin. 5(2), 157-167.

Leton, S. I., Wahyudin, \& Dosinaeng, W. B. D. (2019). Hearing-impaired student ability to solve the problem in math. Journal of Physics: Conference Series, 1321(2). https://doi.org/10.1088/1742-6596/1321/2/022111

Marschark, M., Paivio, A., Spencer, L. J., Durkin, A., Borgna, G., Convertino, C., \& Machmer, E. (2017). Don't assume deaf students are visual Learners. Journal of Developmental and Physical Disabilities. 29(1), 153-171. https://doi.org/10.1007/s10882-016-9494-0

Mekonnen, M., Hannu, S., Elina, L., \& Matti, K. (2016). The self-concept of deaf/hard-ofhearing and hearing students. Journal of Deaf Studies and Deaf Education. 21(4), 345-351, https://doi.org/10.1093/deafed/enw041

Nieveen, N. (1999). Prototyping to Reach Product Quality. In Design Approaches and Tools in Education and Training. https://doi.org/10.1007/978-94-011-4255-7 10

Nikolaraizi, M., Vekiri, I., \& Easterbrooks, S. R. (2013). Investigating deaf students' use of visual multimedia resources in reading comprehension. American Annals of the Deaf, 157(5), 458-473. https://doi.org/10.1353/aad.2013.0007

Nunes, T. (2002). An Intervention Program for Promoting Deaf Pupils' Achievement in Mathematics. Journal of Deaf Studies and Deaf Education, 7(2), 120-133. https://doi.org/10.1093/deafed/7.2.120

Pagliaro, C. M. (2012). Mathematics Reform in the Education of Deaf and Hard of Hearing Students. American Annals of the Deaf, 143(1), 22-28. https://doi.org/10.1353/aad.2012.0089

Pagliaro, C. M., \& Ansell, E. (2012). Deaf and hard of hearing students' problem-solving strategies with signed arithmetic story problems. American Annals of the Deaf, 156(5), 438458. https://doi.org/10.1353/aad.2012.1600

Thiagarajan, S., Semmel, D. S., \& Semmel, M. I. (1974). Instructional Decelopment For Training Teachers Of Exception Children. A Sourcebook ERIC.

Swanwick, R. (2016). Deaf children's bimodal bilingualism and education. Language Teaching, 49(1), 1-34. https://doi.org/10.1017/S0261444815000348

Syafrudin, T., \& Sujarwo, S. (2019). Pengembangan Bahan Ajar Untuk Pembelajaran Matematika Bagi Siswa Tunarungu. Suska Journal of Mathematics Education. 5(2), 87-94. https://doi.org/10.24014/sime.v5i2.8170

Van der Sandt, S. (2018). A case study: Teachers' confidence in theirown and their students' abilities in deaf/hard of hearing high school mathematics classrooms. Issues in the Undergraduate Mathematics Preparation of School Teachers, 5(2), 1-15.

Vosganoff, D., Paatsch, L. E., \& Toe, D. M. (2011). The Mathematical and Science Skills of Students who are Deaf or Hard of Hearing Educated in Inclusive Settings. Deafness $\mathcal{E}$ Education International, 13(2), 70-88. https://doi.org/10.1179/1557069x11y.0000000004

Zakia, D. L., Sunardi, S., \& Yamtinah, S. (2016). Pemilihan dan penggunaan media dalam pembelajaran IPA siswa tunarungu kelas XI di kabupaten Sukoharjo. Sainsmat: Jurnal Ilmiah Ilmu Pengetahuan Alam, 5(1), $23-29$.

Zevenbergen, R.,Hyde, M.,\& Power, D.. (2001). Language, Arithmetic Word Problems, and Deaf Student: Linguistic Strategies used to Solve Task. Mathematics Education Research Journal 13(3), 204-218. https://doi.org/10.1007/BF03217109 